\title{
The ontology of espionage in reality and fiction: A case study on iconicity
}

\author{
Frederik Stjernfelt \\ Department of Comparative Literature, University of Copenhagen \\ Njalsgade 80A, 2300 Copenhagen, Denmark \\ e-mail: stjern@hum.ku.dk
}

\begin{abstract}
A basic form of iconicity in literature is the correspondence between basic conceptual schemata in literary semantics on the one hand and in factual treatments on the other. The semantics of a subject like espionage is argued to be dependent on the ontology of the field in question, with reference to the English philosopher Barry Smith's "fallibilistic apriorism". This article outlines such an ontology, on the basis of A. J. Greimas's semiotics and Carl Schmitt's philosophy of state, claiming that the semantics of espionage involves politology and narratology on an equal footing. The spy's "positional" character is analyzed on this basis. A structural difference between police and military espionage is outlined with reference to Georges Dumézil's theory of the three functions in Indo-European thought. A number of ontological socalled "insecurities" inherent in espionage and its literary representation are outlined. Finally, some hypotheses are stated concerning the connection between espionage and literature, and some central allegorical objects - love, theology - of the spy novel are sketched, and a conclusion on the iconicity of literature is made.
\end{abstract}

The very fantasy of a spy's life, the loss of his own identity, his pursuit of pseudo-information through pseudorelations, makes him a sort of hero of our time.

Malcolm Muggeridge

Politology and historiography contain an enormous amount of concrete studies of famous espionage cases and agent operations, 


\section{Frederik Stjernfelt}

concerning the activities of both domestic and foreign services. Similarly, cases of this kind have caught public imagination to a huge extent with a whole genre - that of the spy and the agent novel - as a literary result. Just like its cognate the detective genre rises with Poe and Rue Morgue, the spy novel is born, albeit more gradually, with Kipling, Conrad, Ambler, Greene, Somerset Maugham, etc., to grow into one of the 20th century's stable and comprehensive literary subgenres.

It is a strange fact, however, that despite its firm grip around the imagination of the 20th century, both in fact and fiction, espionage does not seem to have given rise to any significant amount of principal scientific treatment. No classic piece of writing betitled Vom Geheimdienste by a Clausewitz exists in politology. ${ }^{1}$ Despite the constant and delicate tension between the existence of secret services, necessary for the security of a democratic society, on the one hand, and the same democracy's basic principles about open administration, human rights, and equality, on the other, no tradition for deeper, theoretical understanding of this necessity and these tensions seems to exist. It is almost as if the natural secrecy of the subject is mirrored by a secrecy covering the principal reflection on it - whereas on the other hand both the factual and the fictitious coverings of single, concrete cases explode. The latter seems, in fact, to constitute a huge corpus of casebased reasoning governing the public - and maybe also the services' own - reasonings about the tasks, the constraints, and regulations of the services.

\section{Smith and Schmitt — fallibilistic apriorism}

I shall here attempt to outline the ontology of espionage, as a basis for the factual as well as the fictitious cases and for the possibility of iconicity holding between them. The clever reader will be quick to intervene: do I not confuse two separate problems? Is the description of the espionage novel not a piece of narratology dealing with genre

\footnotetext{
1 Clausewitz's Vom Kriege is even remarkably sparse as to observations on the role of espionage in warfare; all is a 1-page chapter about "Nachrichten im Krieg" containing little exceeding common sense: "Ein grosser Teil der Nachrichten, die man im Kriege bekommet, ist widersprechend, ein noch grösserer ist falsch und bei weitem der grösste einer ziemlichen Ungewissheit unterworfen" (Clausewitz 1963: 48).
} 
literature - a task for literary studies - while the recurring structures of the object itself, espionage, is rather a task for politology and sociology? It is of course not possible to assume beforehand that these two tasks will be identical, but still it seems to me that a strong argumentation is at hand for the fact that they are intimately related. Not only because of the fact that all reflection of a subject marked "secret" must keep on the distance of abduction from it, relying to some indefinite extent on the imagination and fantasies of the interpreter. But also because the relation between semantics and ontology for actual semiotics is rather different from what was assumed in a tradition running from structuralism to deconstruction and other poststructuralisms denying the possibility of iconicity language and literature. The question of literary mimesis pertains to several different levels: one is the possible similarity between aspects of textual expression and the subject treated (the figure poem as an example); another is the possible depicting value of a text in relation to certain empirical properties of reality (be they factual, as in journalism or science, be they more general like in the discussion of the possibility of literary realism to reveal insights about a given period, society or other issues). The iconicity at stake in the discussion in the following lies at an even more basic level: iconicity at the level of semantic structures used. I shall argue that the spy novel provides an example of this basic iconicity in so far as the very construction and understanding of a spy novel is only possible by the use of semantic concept structures similar to those incarnated in real life espionage cases. ${ }^{2}$

A basis for the discussion might be Barry Smith's radical idea of a "fallibilistic apriorism" extending the philosophical a priori realm to a long range of conceptual structures in the foundations of the single empirical sciences. This a priori domain is not defined by its belonging to any transcendental subject and does not, for the same reason, suffer from any problems of presence. "A priori", of course, signifies validity before (that is, independent of) empirical fact, but there is no reason to assume that this implies that human beings should automatically possess insight in these structures beforehand. Thus, there is no problem in supposing that we, during the development of civilization and of science, become increasingly able to

2 Thus, I use "iconicity" in a broad sense in the tradition from Charles Peirce. I have discussed the theoretical prerequisites and implications of this notion extensively, in Stjernfelt 1999 and 2000. 
uncover ever more extended a priori structures. In the same vein, there is no problem in assuming that we may have fallacious ideas about significant parts of this a priori field (in exactly the same manner as we may be on the wrong track in the solution of mathematical problems which are not empirical issues either) - even if it is impossible that we could be wrong about all assumptions at the same time. Further research may be able to make up for such mistakes hence the nickname "fallibilistic apriorism". ${ }^{3}$ An implication of this idea is that a priori structures cover a far wider field than normally assumed; there is no reason to believe that formal ontology, common to all possible objects, is yet complete, and there is similarly no reason to assume that the single sciences" "material" or "regional" ontologies may not be investigated much more thoroughly than has been the case. The basis of each single science will contain, in its basic conceptual structures, a comprehensive network of interrelated terms of formal and regional ontology. It follows from this idea that works of fiction sharing the same subject as one of these sciences, will also share, to a large extent, one and the same basic conceptual structure. ${ }^{4}$ This is why

3 These lines summarize the conclusion of Smith (1994) with its basis in the Austrian tradition of economics. A priori structures may not necessarily be deduced beforehand and must in many cases be abstracted out of empirical knowledge; thus they are, in a wider sense of the word, founded on an "empiricism", albeit one which must acknowledge two wholly different spheres in experience: an aposterioric domain for what is in fact the case, and an aprioric domain for which stable categories these facts are articulated in. In Peirce's concepts, this would correspond to a factual and a diagrammatic sphere, respectively (cf. Stjernfelt 2000). Subsequently, Smith (1996) has, inspired by Carl Stumpf and other Brentanians, proposed a long series of "Vorwissenschaften" of both material and formal kin - from arithmetics and set theory over geometry and chronometry to chromatology; from rational psychology over aprioric aesthetics and ontology of arts to universal grammar, speech act theory and theories of social interaction. Smith has himself applied the fallibilistic a priori principle to a number of subjects, so as for instance aprioric geography as a subdiscipline of the latter. What follows might be said to be a sketch of an "Austrian" a priori theory of espionage as a branch of political geography, investigating the systematic relations between "spy", "secret service", "sovereignty", "state of emergency", "sanction", "democracy", "law", "fiction", etc. In doing so, this paper will constitute part of a priori politology on the one hand and part of a priori narratology on the other. A meta-insight here will be the mutual dependency of politology and narratology — an idea which Greimas the narratologist would not find strange (even if seen from the perspective of a more scepticist methodology).

4 In the case of espionage, we meet such structures in the recurrent, transhistorical claims about the nature, essence, principles, or problems of espionage in 
Barry Smith's approach entails that the semantics describing the content of a given domain will have iconic affinity to the ontology of the domain (even if many specific differences of course may prevail in the single case). This is the implication of one of Smith's slogans: "putting the world back into semantics".

If we begin, naively, by taking a dictionary definition of a central concept for the agent novel like the term "spy", we will find he is a person who "illegally investigates (especially military) secrets". ${ }^{6}$ This definition refers to a whole range of implicit presuppositions belonging to an espionage script, an underlying highly structured scenario. Deprived of references to that scenario, the semantics of the word "spy" would be ineffable. A spy investigates some subject secretly because of a certain danger or illegality in the investigation which, in turn, is determined by the fact that its subject is the business of some competing power, political or private, domestic or foreign. There is thus an a priori connection between the secrecy of the information and the relative illegality in which the spy indulges. The parenthesis of the dictionary definition implies that the spy typically has been sent out as an instrument to gather information by one power, militarily competing with another power possessing the secrets. Thus it is only in the light of this a priori, more general and more comprehensive, ongoing struggle that espionage becomes meaningful. Any fight sufficiently elaborated in time and space will always imply

spy literature. In Spies and Spymasters, e.g., we read about the 20th century espionage that "though considerate advances had been made in technology, the basic principles and problems of intelligence remained unchanged" (Haswell 1977: 144). In the same vein, we are told that as to the human element of espionage "[...] nothing had changed since the days of Joshua" (Haswell 1977: 146). Such general ideas are subsequently applied in the analyses of specific subjects, as when the espionage satellites of the 20th century are seen as evolutionary heirs to the balloons of the 18th century. They, in turn, had the function "[...] to take one stage further the instruction Moses gave to his spies: "Go up into the mountain, and see the land!" (Haswell 1977: 166).

5 Smith is thus busy founding a center for philosophy and geography and conceives of political geography as an exemplary case for a priori studies, e.g., of border types. The idea of such a relation between reality and semantics remains, though, controversial. The present paper has thus been turned down by several literary journals, not because of its quality (they claimed), but because of the fact that it included real-world issues in the discussion of a literary genre.

6 In an arbitrarily selected dictionary, Nudansk Ordbog, Copenhagen: Politiken 1977. This procedure in inspired by Greimas's investigation of the concepts “challenge" and "anger", in Greimas 1982. 


\section{Frederik Stjernfelt}

that knowledge about the opponent's next move adds to the probability for a positive outcome: this implies it is possible to try to anticipate that move and improve the efficiency of one's own next move. Or one may simulate such a move in order to seduce the opponent to open a flank giving a possibility for an even more efficient move. The agonistic structure of feints, simulated feints, etc. is implied here, as it is well known from mathematical game theory and instantiated in a long series of other fight or game types. The historiography of warfare is to a large extent based on the investigation of such structures of mutual deception strategies. ${ }^{7}$ The raison d'être of the spy as collector of information lies in this scenario of struggle, and his role is to be a tool for one of the agonists of the battle waged.

Here we have isolated a minimal version of the regional ontology of espionage by looking at background presuppositions to a dictionary definition of the word "spy". A more systematic investigation might go the opposite way and try to develop the concepts of war, fight, game, or battle in order to distill espionage as one of the possible moments of fighting. A project of this kind is to be found in A. J. Greimas's narratology. Despite its apparent simplicity, this narratology remains one of the most sophisticated instruments to analyse narrative structures. ${ }^{8}$ At a first glance, the "narrative schema" of this theory is deceptively simple: a Destinator, defined as an actant impersonating central values, sends out an Operator Subject in order to solve a certain task. This subject is endowed with certain competences

\footnotetext{
7 A prominent example is the allieds' large-scale deception operation before Dday in order to make Hitler believe the Dunkirk area to be the invasion spot, including not only a planning of a feinted invasion there but also the planning of a feinted feint, a more northerly invasion supposed to take place from Scotland, thus adding further credibility to the Dunkirk possibility.

8 I believe this is not generally acknowledged, and among many literary scholars, Greimas even counts as an especially malign reductionist. This rests, however, upon a misinterpretation of Greimas" "narrative schema" as an assumedly identical deep structure underlying all concrete texts. This idea overlooks a crucial moment in all decent structuralisms: the concept of transformation. The schema must be transformed in order to grasp the single text's specificity. The specific features of the single text is grasped only by understanding - not only the schema - but the specific transformation (and its motivations and implications) resulting in just that text. Moreover, the schema may develop with the addition of further assumptions which make new aspects of the fight appear. The schema is not a causal regularity, it is a teleological regularity, and hence it may bifurcate at every possible joint, not satisfying the telos in question.
} 
by a Helper during a first "qualifying" trial; then follows the "principal" trial where the Subject tries to beat an Anti-Subject in order to take some Object in his possession. Back at the Destinator's, the Subject presents his results in a third and last, "glorifying" trial and he receives - if the result is convincing — a Sanction judging the Subject's efforts. If the Subject wins this trial, he may receive a final Object as a reward or trophy. These three trials may, in specific cases, be realised in highly different ways, ranging from regular wars and to peaceful exchanges. A version of it clothed in fairy-tale garments makes the schema more intuitive: a King is threatened by a Dragon who has abducted the Princess, and he sends out a Hero to make up for it. The Hero must first gain a magical object or competence from some Sorcerer and he may now kill the Dragon and free the Princess. Back at the Court, the Hero displays the saved Princess and receives a reward, maybe the Princess and half of the Kingdom. If this schema is so apparently simple, then it is probably due to its omnipresence in human imagination rather than to an inherent simplicity, not to talk about triviality. The schema contains a complexity generator due to the fact that every single phase of it refers to intersubjective relations with all the possible mirrorings, dialectics of recognition and possible misunderstandings involved. This has as a consequence that the schema may "develop" in a huge bouquet of different directions. The interaction between two actants which is in one version a raging battle may in other versions be a completely peaceful exchange - and, what is more, in each phase the teleological development mapped by the schema may go wrong. Maybe the Hero is too afraid to go to war; maybe the Sorcerer refuses to let go of his medicine copyright; maybe the Dragon actively tries to get rid of the awful Princess; maybe the King stubbornly sticks to both halves of his Kingdom; maybe there is a secret alliance between Dragon and King in order to fool the public, etc., etc., and etc. As is evident, the schema is extremely plastic with respect to variations - at the same time as it has the stable character of being a prototype for the mapping of socially integrable actions in general. As an addition to this powerful variability, the staging of narrative events in more or less artful enunciation may select single phases of the schema to emphasize and elaborate, while other phases are neglected. It may, moreover, display the events narrated, as seen from changing points-of-views of different actants, and, finally, it may recursively repeat the realization of it in different versions including the substitution of characters filling the actant roles and the 
embedding of local versions of the schema into more encompassing versions.

But the very question of social integration implied in the relation between Destinator and Subject guides us on our way to the status of the spy in this schema. Of course, espionage may occur in each of the phases in the schema - in so far as the secret obtaining of secret information may be desirable in all intersubjective relationships. But because the Destinator incarnates socially stable values, the character of the Hero's task is decisive for the interest taken in the narrative in question. If the Hero's task follows ordinary procedures as governed by central administration, little remains to be told ("Once upon a time, there was King who should send a document to the council in one of his towns. He gave the task to one of his very best couriers, and the document did in fact reach its goal regularly. The courier received his contractual wage and lived happily ever after."). A procedure of this kind is of course covered by the narrative schema's domain of modelisation, but for a narrative to be interesting it is well known that it must contain some moment or other of norm break. This is, in fact, already implied in the distinction between Destinator and Operator Subject: the frictionless action might as well be undertaken by the Destinator himself (if the Destinator in case is, e.g., central administration). The King might himself grab his good sword all at once and force it through the heart of the dragon. But he must have another actant do it, even one who receives occult, extraordinary, abilities from some Sorcerer, that is, a person incarnating a competence transgressing what is usual and lawbound. The killing of the Dragon, moreover, most often takes place far from home - that is, far from the regular domain of laws and outside of public control. In this extraordinary competence in the Hero lies as a germ espionage, and more broadly, the secret agent, as an aspect of the Hero's deed. The Hero constitutes his own Special Task Force, and his deed is in itself a Covert Action. Now these features in the Hero actant do not distinguish the spy as opposed to e.g. the warrior, the detective and similar stereotypes derived from the same basic structure in the Hero.

Consequently, further differentia specifica must be found in order to grasp the difference between spy, detective, soldier, and the correlated fiction genres. We may as a first preliminary emphasize that the three of them share the Hero's character of being exceptional. The detective novel does not have the regularly working police officer as its hero, the war novel does not have the average, ordinary soldier as 
its hero. The detective novel favors precisely the private eye, and even more so, the deviant private eye who does not do his work "by the book" but differs from the police in two respects: he does not, like they do, act correctly according to the rules, and, conversely, he is not involved in their muddle of corruption and mafia deals. Exactly because he does not act "by the book" he may, paradoxically, act by the spirit. Even if we focus in fact on a regular police officer in the corps, we most often chose a deviant cop whose personal character and working methods transgress the average (model Colombo). Analogously, the modern war novel generally takes the point of view of a rebellious private, despising his superordinates far and comfortably removed from the front line, not following orders. Thus, this "front pig", being an uncompromising survivor, may perform especially dangerous services. What distinguishes the spy - and the spy novel - from these stereotypes is that while the private eye and the front pig form individual cases of deviancy in the service of a higher cause (which they may serve so much more efficiently because of their disregard for rules), then the spy's deviancy is systematical. The very service which he is working for, constitutes an anomaly in modern society. ${ }^{9}$ The secret service is so to speak an institutionalized deviancy inside the state, a whole state organization characterized by not being forced to do things "by the book". As contemporary conflict researchers (like in Scandinavia Ole Waever and Ola Tunander) have emphasized, we must turn to obscure political thinkers like Carl Schmitt in order to understand the specific character of these organizations. Schmitt began his classic of philosophy of state Politische Theologie from 1922 with the famous words: "Sovereign is he who determines the state of emergency ...". In the context of Greimassian fairy tale logic, it is the Destinator who commands the state of emergency. ${ }^{10}$ Ordinary law is only valid in so far a state of emergency is

9 Here sociological criteria enter: espionage does not seem to have been anomalous in GDR (German Democratic Republic), for instance, measured on what is known about the number of informants in the people employed by the Stasi, and generally espionage is considerably less controversial in pre-democratic or totalitarian states. But even here, the anomalous character is preserved in the secrecy of procedures.

10 Carl Schmitt's personal carreer is highly controversial, involving extreme right wing positions and support for the nazi regime in the 30s. Despite Schmitt's dubious - to say the least - political positions, it is possible to discuss his more general philosophical and scientific points of view on a democratic basis. Schmitt's notion of sovereignty is explicitly mapped from theological concepts, 
not declared - and the actant who decides whether the normal state prevails is of course endowed with the power of suspending it, to some (larger or lesser) degree depending on his own judgment only. Schmitt's cynical tradition turns Clausewitz upside down: the universalization of the schema of Friend and Foe makes politics a war continued with other means. ${ }^{11}$ In such a tradition it will be a corollary that a preparedness outside ordinary legality must be kept, also during (apparent) peacetime. The state of emergency is always potentially present, and for this reason an organization is needed which is continuously able to judge which extralegal means are necessary to cope with occurring threats against the security of state. ${ }^{12}$ Schmitt is, for this reason, the Cold War's theoretician avant la lettre: any peace is according to him nothing but a cold war. In the Greimassian narrative schema the agent and the spy thus belong to a scenario in which the Destinator as a sovereign stops doing things by the book - and turns, instead, to the Schmittian book.

\section{The man who knew too much - the positional character of the spy}

This implies a series of distinguishing features in the spy as a potential aspect of the Hero - in contradistinction to the detective and soldier characters. In the most comprehensive and detailed text analysis which Greimas undertook - the booklength Maupassant reading Maupassant, the short story "Deux Amis" has as its main theme precisely: espionage. During the Prussians' siege of Paris in 1871, two Parisian friends go fishing, and they receive a paper passport in order

cf. the hypothesis of Politische Theologie that modern political theory is constituted by secularized theology. A corollary is that fundamental political and politological issues inherit structures from theology; the political wars of the largely atheist 20th century support this idea. It is easy to recognize the problems of incarnation and of theodicée in relation to espionage: how may democratic ideas become flesh? How can democracy be morally good when its own secret services are not?

11 Schmitt does not explicitly claim this, but the idea clearly appears, e.g. in Der Begriff des Politischen, (Schmitt 1963: 34n) where the famous dictum of Clausewitz is interpreted with the conclusion that politics is determined by the Friend-orFoe logic of war.

12 The latter expression is, surprisingly, rather new and dates back only to American discussions in the beginning of the Cold War. 
to cross the French lines into no-man's-land (which is a peaceful zone, there is still 40 years to the 1st World War). After fishing, they are picked up by a Prussian patrouille who demand that they reveal the password they are supposed to possess in order to pass the French lines. They are unable to do so, of course, as the do not possess any password, and they are executed. Greimas' detailed analysis finds that this killing represents the cruelty of power (especially Prussian power) as opposed to heroic citizens keeping a secret. The Danish semiotician Per Aage Brandt has, at this point, caught Greimas in a misinterpetation with crucial implications for the status of the spy. The two Parisians do not possess the password which the Prussians believe (they only have a paper passport), and they are unable to say what they do not know: they do not keep silent for heroic reasons. Correspondingly, the Prussian officer is not personally cruel, he just acts conforming to an ordinary logic of warfare. ${ }^{13}$ The two of them have in fact seen the position of the German lines, and if they are allowed to get back behind the French lines, no Prussian may hinder them from informing the French defense. Even if the two fishermen are by no means spies, neither intentionally nor institutionally, they invariably become spies, functionally, because they are who they are where they are (Brandt 1983: 129). If you take a walk on a secret military area with your camera - we may recall certain Danish tourists arrested in Poland in the mid-eighties - then you are a spy, no matter whether the reason you do so may in fact be your innocent interest in a rare bird. In this light, the Prussian is not cruel, he just acts according to the jus necessitatis of war - exactly the same principle according to which secret services act during the cold war of peace. A classic of this species constitutes the Profumo affair, in which the British secretary of defense was forced to quit because he kept the same mistress, Christine Keeler - whether she took herself paid for her services or not - as a Russian intelligence officer, Jevgenij Ivanov. It is improbable that Keeler did in fact hand over sensitive information

\footnotetext{
13 We presuppose, of course, that the Prussians did not have the possibility of incarcerating the two and keep them as prisoners of war. We may note en passant that according to John Keegan, it was the Prussians' victory in the Franco-German war which made Clausewitz an international hero in military academies worldwide. This development formed part of the reason for the radical brutalization of war during the 20th century because of Clausewitz's idea of the war as tending to the utmost release of violence.
} 
to the latter, but the simple fact of her position in the scenario was sufficient to release the scandal. ${ }^{14}$

This is of course the reason why it may be very important for the state to keep a file on persons with access to classified material. If they — who positionally are potential spies — should decide to become spies in actu, then they must be made silent. They may be forced, for instance, to go out in the press and discredit themselves, maybe declare themselves insane, so all their sayings become polluted with ambiguity - and then they are maybe rewarded, in secret, with a pension that they would not have received under other circumstances. The specific methods of pressure are many, but the structure is stable - it is, as we know from a classic of the spy genre: it is impossible definitely to come in from the cold when you have first been out there. When first you have had been a spy, then you keep on being it, positionally, no matter what you may personally decide, because you now have the property of knowing too much. This logic of position implies that the spy is a radical example of impossibility of social reintegration. It is a well-known fact in fairy-tales that when the victorious Hero returns home with a Dragon's ear in one arm and a Princess in the other, a narrative problem may arise. Why should he be satisfied with a Kingdom and half of the Princess or whatever the King will offer - he, the Dragon slayer, who achieved what the King himself could not? Why shouldn't he take it all? The military coup as a structural possibility is inherent in this argument, just like revolutions, stabs-in-the-back and so on, and during peacetime this logic seems to underlie the notoriously difficult reintegration of veterans after great wars. The extreme level of excitement and fear, the fact that every moment and every action concern life and death, the ultimate dependency upon the small Männerbund at the front and its unconditional friendship - all these experiences may make an ordinary civil life seem like a dull superficial existence. It has often been remarked that the rocker organisations Hell's Angels and Bandidos were founded by American veterans from the Second World War and the Vietnam War, respectively, and the same goes for Nazism's

14 Analogous cases occured in USA during the same period - president Kennedy's affair with Judy Exner whom he shared with mafioso Sam Giancana, just like his affairs with the Eastern German girl Ellen Rometsch and several upper class whores with connections to the Profumo case. These affairs were only made silent with intensive emergency work by Robert Kennedy and J. Edgar Hoover (according to Hersh 1998). 
triumph in the twenties and thirties which was only possible due to the support from enormous self-organized bands of First World War veterans in the SA and related Freikorps. The reintegration of the veterans is a psychological (and in large number cases a sociologial or political) problem which may be contained by different means - the reintegration of the spy an individual problem (and of course no large scale social problem), but then again so much more impossible. The spy may sing until he is dead, and hence he must be bound with pensions, threats, blackmail etc., because he cannot leave the position of knowledge he now occupies. This structure is what, conversely, makes it possible for a spy to blackmail or punish his former organization if it does not treat him as expected. The British spy Leslie Nicholson was stationed in Prague in 1930 and spent 20 years there in the service of the SIS. When his wife became ill, he asked C, Sir Stewart Menzies (the "M" of the Bond novels) for a loan which was refused. After his wife's death, Nicholson emigrated to the USA and took revenge on the SIS by publishing his British Agent there in 1964. ${ }^{15}$ Peter Wright's Spycatcher from 1987 is a related example.

\section{Two service types}

The stable security structure of post-war 20th century in most countries features two organizations, foreign and domestic, and with connections to the military and the police, respectively. This structure has ancient roots (even if there was a tendency until the Second World War that services were founded $a d$ hoc and cancelled in periods of peace $^{16}$ ) and gives rise to a stable set of differences. Codes of honour based on mutual recognition is considered a military virtue and tend to have a certain influence on the former, while the latter in its tendency mirrors the radicality of civil war as opposed to interstate warfare. Police-based services have as their object the state's own citizens (or domestic foreigners) conspirating against the security of the state in which they live. Thus, they are aimed against traitors who are not seen as objects for the soldier's (potential, that is) gentleman-like behaviour

\footnotetext{
15 According to West 1993: 296-297.

16 Famous is the alleged refusal of the USA to perpetuate the services in the period between the World Wars, with reference to the fact that "gentlemen do not read each other's mail".
} 
towards other soldiers only accidentally serving foreign powers, maybe being forced to do so by conscription. The French historian of religions Georges Dumézil once made an interesting observation in this respect when he discussed the relation of freedom to the second function (the military one) of Indo-European religion and ideology. ${ }^{17} \mathrm{I}$ translate the relevant passage from an interview:

Jacques-Alain Miller: Generally, as you analyse it, the second function displays a paradoxical aspect, because it effects the socialization of rather asocial features.

Georges Dumézil: It is dangerous, but exactly for the reason that it does not respect laws, it may also happen that it may give rise to happy exceptions in those procedures where summum jus summa injuria. [cf. later in the interview: $G D$ : The warrior is a creature who in all cases, not only sexuality, is always on the limit between the legal and the illegal, the ordinary and the exceptional.]

$J A M$ : Thus you write that 'the warrior keeps the features which takes him away from ordinary people and even puts him in an opposition to the social order which he has as his task to protect when necessary'.

$G D$ : The possibility for opposition to the social order can appear for better and for worse. Deep down, it corresponds to the opposition between army and police. During the German occupation it was the opposition between Wehrmacht and Gestapo. It was much better to be involved with the former than with the latter. How could I forget the Mauss incident? He was saved because his flat had been claimed by the army ...

$J A M$ : But doesn't the army represent the military function here?

$G D$ : Yes. The army needed his apartment and its terrace at eighth floor, close to Porte d'Orléans, for anti-aircraft defense. One morning, I was at Mauss's place when a colonel, in a brusque but friendly manner, made him understand that the respite which he had been given had run out. Mauss negotiated and eventually got a new respite. Thanks to this, his library could be transported to the Musée de l'Homme and he himself could move into another place fifty meters from home in a flat required by the army.

Jean-Claude Milner: That is Mars Tranquillus?

$G D$ : Let us say that is military honour.

JCM: And the Gestapo?

$G D$ : They represented, unfortunately, the first function. Police has to do with the first function. The RigVeda calls the stars "spies" for the sovereign god Varuna.

17 The military function is the second function out of the three in Dumézil's theory of three main functions in Indo-European culture: justice/magic, war, fertility.) 
Alain Grosrichard: That implies that deep down the descendants of the Germans still used trifunctionality during the war?

$G D$ : Let us not go that far. Let us just say that by coincidence, Gestapo's and the Party's relation to the army now and then mirrored the mythical depth of the relation between Varuna and Indra.

$J C M$ : You have written by several occasions that German culture has underlined two aspects of the second function: its violent side, the military gang, the Männerbund, as well as its autonomous side, freedom. But when I read you I have in the back of my head texts by 19th century historians claiming that the individual liberty was born in the forests of Germania. Is it possible, according to you, to find a sort of matrix in German law rather than Roman law, tied to the second function, which might serve as the structure in some sort of freedom?

$G D$ : A priori, it does not seem improbable. Let us think of the thing, the English and Scandinavian parliaments. ${ }^{18}$

Apart from the fact that the right-wing royalist Dumézil here appropriates a Scandinavian-German myth about the origins of freedom which must have been felt like an insult on the Left Bank, the distinction made is interesting. The warrior makes possible freedom, honour, mutual recognition and has his place on the limit between law and transgression; the high priest and judge — and their spies — of the first function seem highly elevated over that very limit. The spy and the police are connected to the somber first function which, unlike the second, has nothing to do with freedom, autonomy, and honour. We glimpse the ravens of the first function sovereign deity Odin, these scouting scavengers, as an archetype of the spy - and the crafty Odin versus the brave Thor as an adequate Nordic icon of the Indian Varuna/Indra distinction. According to this distinction, the first function's police is thus less democratic and concerned about rights than is the second function's army ${ }^{19}$ — and the intelligence services of the two organizations accordingly, although both tend towards the first function side of the distinction so that army intelligence rather forms a sort of intermediate compromise between the constraints of the two functions. The first function, however, is superordinate to the second, it is exactly sovereign, also in a Schmittian sense of the word, because it is a task of the first function to determine whether ordinary law prevails. Prisoners of war are respected due to conventions and are

\footnotetext{
18 From Ornicar!, vol. 19, Paris 1979.

19 We may remark the British military historian John Keegan's empirical claim that the Napoleonic revolutionary armies with their general conscription played a crucial role in the democratization of Europe.
} 
returned to the enemy after the war; foreign spys are relegated, while the country's own undermining forces are classified as traitors and even criminals of an especially malign type - this indicates that Dumézil's distinction remains valid in our days foreign and domestic services and their different treatment of their opponents.

The foreign services meet as their opponents organisations, similarly organised and equipped, from enemy or neutral (or even friendly) states. This implies a mirror structure we recognize from many spy novels, and it entails defection as a constant possibility. For the double, triple or nth level agent it is a possible way out when the earth is burning beneath him and the threat of exposure comes close; for the agent in general a way out, also to escape from other possible, maybe personal problems. The capital you may use to buy defection is, of course, inside knowledge which will subsequently be paid off in longstretched debriefing sessions. The defector will now find himself at the mercy of the receiver country and an obvious possibility is the emergence of a new relation of mistrust given by the fact that the defector's interest is to feint more knowledge than he actually has and to delay the disclosure of it until he has gained maximal advantages from it. Domestic services most clearly representing Dumézil's first function are only part of this mirroring by their involvement in counter-espionage, while its other measures taken against the state's own citizens do not face a similarly organized resistance. In return, the interior service must suffer from a structural paranoia due to its status as subject to a controlling Destinator in the form of public, parliamentary control. ${ }^{20}$ It may seem natural for this service to act as an autonomous instance - also in a stronger sense than indicated by the natural Weberian tendency of all bureaucracies towards secrecy. Thus, it may seem a matter of course for it to extend its interests also to powers or persons which may not be a threat to security of the state but are merely threats to the service's interests, that is, politicians or writers with critical or even merely controlling intentions related to the services. A continuum thus stretches from security of state and to security of the service, and it is hard to exclude the possibility that a service may in case of crisis chose the latter rather than the former. The military coup is, by a homologous structure, the foreign service's

20 Of course, military intelligence is subject to the same control, but the recurrent and delicate political tension between state security and the human rights of the same state's citizens is structurally relevant for domestic services primarily. 
corresponding possibility; the domestic service's possible unfaithfulness is bound to follow less conspicuous ways - for an unverified example, take the recurring rumours about right wing circles in the Stockholm secret police $S € P O$ and their support for the Palme assassination. ${ }^{21}$ According to Seymour Hersh's recent book on Kennedy's presidential period, it was the case that J. Edgar Hoover was able to guarantee his continued leadership of the FBI under the newly elected president (who disliked him) by maintaining huge dossiers involving sensitive information on Kennedy, including his first and blacked-out marriage in the forties. ${ }^{22}$

Generally, democratic control with such organizations is by nature a delicate issue. Control commissions must keep silent, even regarding the participants' own political parties, and on the other hand, how can a commission make sure it has received access to all relevant information from the services? This tension has a principal a priori character, in so far as total public control with such organizations would severely limit or even reduce their possibility of action - it is a given thing that such organizations must, for the sake of efficiency, be given a certain margin in which to operate, both as regards secrecy and as regards violation of law for the sake of security - even if this fact makes the organizations constantly vulnerable to potential public scandals. The old saying, attributed to Lenin: trust is good; control is better, cannot be applied here. The problem about control of the controller leads, of course, to an infinite regress which is only doubled by the necessary secrecy in the control of secrecies. Control must, sooner or later, at some delicate level, meet a limit, beyond which only trust remains. ${ }^{23}$

21 Cf. the Swedish conflict researcher Ola Tunander's work on the Palme case.

22 When the present senator Moynihan (cf. below), after having served under Kennedy, Johnson, Nixon, and Ford, was elected to the Senate, he got admission to his own FBI file of 561 pages, naming him as a communist.

${ }^{23}$ In one of the rare cases of principal reflection on these issues - the last chapter of former CIA-boss Allen Dulles's book The Craft of Intelligence (1963) - he claims that the president himself controls the services, that Dulles himself has supported a proposal for a civil control commission, that all his own knowledge of the services gives reason for trust: "After more than a decade of service, I can testify that I have never known a group of men and women more devoted to the defense of our country and its way of life than those who are working in the Central Intelligence Agency." (Dulles 1963: 264). Apart from the fact that a natural scepticism is easily felt towards a claim like that from the leader's own lips, it remains correct that it is assumptions like the ones quoted that 


\section{Two insecurities}

A further a priori necessity in the spy and agent characters is the particular recruitment circumstances. No matter how upright, welleducated, and clear-minded the leading figures in an intelligence organization are - and they must be, if any - they are in no position to impose the same requirements on all their subordinates. To the dirty work, they will have to use occurring characters of different kinds. The asymmetry between Destinator and Hero thus multiplies internally within the organization: the director of secret actions must make use of concrete tools operating in that part of reality which must be kept under surveillance, influenced and manipulated - and for secrecy reasons it is obvious that you can not arbitrarily plant anybody anywhere. You must, to a large extent, use persons who by coincidence have a character, a past or a position making it possible for them to fit unseen into the milieu in question. And this implies that you cannot afford to be too fastidious: this is not tasks which it is possible to educate people to fulfil, except for - exactly - exceptional cases. This does not imply unfaithfulness as a necessity but as an always threatening limit possibility: this personnel outside of perfect control consists to some extent of misfits, persons of a peculiar psychology, persons who for odd reasons feel attracted to intelligence work, people who feel drawn by sinister affairs, people who undertake such duties of bitter necessity, people who are easy to threaten to do such tasks - even if you may ever so much hope that their main motivation be idealist. As in so many aspects of intersubjectivity, these actors' motivations are hard to determine: idealism, loyalty, excitement, desire for recognition, money, threats, brute force ... the manifold of possible motivations implies that the superordinate person will have a tendency to make sure that he, just in case, has access to the latter means of influence. This insecurity implies that an elementary relation of mistrust inside the organization is obvious - which is proved by the many cases of important information that was not taken seriously. Dusan Popov informed the American army about the

you have to rest your head on. On the other hand, Dulles adds immediately afterwards, as the last two sentences of the book that "The last thing we can afford to do today is to put our intelligence in chains. Its protective and informative role is indispensable in an era of unique and continuing danger." (Dulles 1963: 264). Dulles thus summarizes in a few lines all possible points of view: control, trust, limitation of control ... 
Japanese Pearl Harbor plan but he was not believed; the Russian Western intelligence was well-informed about Operation Barbarossa, but they were in no position to convince Stalin ... this insecurity spreads like a fog in the relation between the intelligence organization and its own informants and henchmen on all levels. An obvious danger in this fuzzy world is that the organization believes what it wants to believe, and it must face the paradox that the more information a message contains - that is, the more surprising it is - the less probable is it that the message will be believed.

This top-down insecurity is doubled, however, by a parallel and even more decisive bottom-up insecurity. For security reasons, the single agent must of course know as little as possible about the general plan of which he forms a part - not to speak about other parallel operations - but this necessary "compartmentalization" of information and tasks implies a fundamental insecurity about the very character of the operation as seen from below. ${ }^{24}$ Not only is the individual, like in all struggles, at a feint's distance from the enemy and his intentions; this basic indecidability is doubled, for the spy, by a parallel insecurity as to the exact intentions of his own side. This structure has its most prominent result the heavy weapon of counterespionage, the double agent, who acts as if he belongs to one side while employed by the other (probably, maybe his sympathies are changing ...). You will never know, as a spy, if your spymaster or leading officer is miserly with information because his deepest sympathy lies elsewhere - cf. the classic uncoverings of the third, fourth, fifth man of the Cambridge Five, all of whose existence was known long before a name could be singled out. This structure entails that a fundamental insecurity spreads in the whole spy world, pinpointed in Len Deighton's description of how Bernard Samson's own wife Fiona all of a sudden disappears as the enemy's most treasured double agent. This insecurity has several sources (apart from the enemy's natural attempts at spreading fog): the insecurity whether the mission you are

24 An actual Danish example is the schoolmaster Kristian Kjaer Nielsen who recently (in the Danish daily Information March 10th 1999) told about how he spied as a member of the Danish Neo-Nazi Party DNSB in the seventies. The information he collected was delivered anonymously by postbox in Copenhagen, and the spy had never any clear idea as to who his commissioners were. Obvious candidates included Israeli, West German, and Danish intelligence services, just like Jewish organizations for the tracing of Second World War criminals is a possibility. 
on has a real purpose or if it is rather a deception operation destined to fool the enemy while the really important operation takes place elsewhere; the insecurity whether the mission you are on is in fact planned by double agents in your own organization; the insecurity whether your own organization does in fact attempt to satisfy the goals it presumes and not completely other purposes.

In extreme cases an agent may, as a "useful idiot", function as a tool for an organization without even knowing it himself. And not even such matters may be settled by archive files - because a spymaster has his own interests, in turn, in relation to his superordinates on a higher level. A well-equipped archive with "agents" and "spies" may keep him safe, even if the persons mentioned are to a large extent not at all spies but only people to whom he maintains loose contacts.

In the secret organisation, the very secrecy principle has an ambiguous character which adds to the spreading of fog. The basic motivation for secrecy is naturally immanently given: the enemy must not know what we know. But to this, a procedural secrecy is quickly added: the enemy must not know the illegal procedures undertaken in order to gain information etc. - this becomes in itself a potential conflict cause. And this problem doubles once more internally in democratic societies: the public must not know (too much) about the types of method used because this may delegitimate democracy's own laws and ideals. These constraints have led to a violent growth in the use of the three classic grades of secrecy: confidential, secret, and top secret. In the American context, this has recently been investigated by senator Moynihan (1998) finding that the extent of secrecy is now so all-encompassing that it forms a threat to the very efficiency of the services, and, in the last resort, to the security of state. Secrecy is naturally a basic problem in an open society, but in addition to that comes the fact that secrecy may blind the intelligence organizations for important real-world facts. Moynihan predicted the fall of the Soviet Union as early as in the late seventies, and he wonders why the CIA did not have the slightest idea of what was to come, even immediately before the breakdown - in spite of the obvious crisis in Soviet economy and the international decline of Marxism as an ideology. ${ }^{25}$ Too much secrecy not only entails that the organization

\footnotetext{
25 Moynihan relates, not without comical effects, how general Butler, one of the main responsibles for the American atomic strategy, visited the Soviet Union for the first time in 1988 and got a shock. Everything is falling apart, and the chauffeur in the official limousine transporting him breaks off the gear stick. After
} 
may loose grasp of its own informations; it may, furthermore, lead to the widespread misunderstanding that just because something is marked Top Secret it is eo ipso true. But even worse, Moynihan argues: the enormous increase in secrecy has given the American services a reputation as state monsters turned against the population, and a frightening statistics proves that around three fourths of the American population believe in conspiracy theories involving the services, among them the Kennedy and Martin Luther King assassinations, the lore about the secret military shootdown of ufos and obduction of extraterrestials at Roswell in the fifties - and much more. The extent of secrecy thus may threaten to destabilize the very relation between state and population - and Moynihan proposes a radical intervention. Obligatory discharge of secrecy marked material after 10 years (of course with the possibility of withholding special cases). In all cases, his diagnosis is thought-provoking: the very act of secrecy may contribute to inefficiency as well as to discrediting of the organization using it.

It is thus a part of the nature of espionage that a potential insecurity spreads at all levels. This should not, of course, hide the fact that most of the everyday work in such an organization is probably completely undramatic and is concerned with information taken from official or other public sources. Very often $75 \%$ is mentioned as an estimate of the part of the organizations' work which remains completely untouched by such insecurities. But even if the insecurities do not have to be part of one and every operation, they are constantly present as a potential limit condition. Moreover, they are most often involved in sufficiently complicated, spectacular, and embarrasing cases which is why they play a main role in the spy literature - cf. Muggeridge the spy's quote at the beginning of this paper.

all these years, Butler realizes in one second that he has been dealing with a caricature (Moynihan 1998: 78-79). Moynihan himself tells about a parallel experience by the Sandinists where he, as an official guest, is witness to the secretary of interior trying in vain to have served beans at a restaurant - all at the same time as the illegal Iran-Contra scandal develops on a CIA-automatic idea that the Sandinist state should be a strong and dangerous enemy (Moynihan 1998: 208-212). Instead, Moynihan's proposal would be that a “... reasonable American response to the new Communist government in Managua would have been a statement of condolence" (Moynihan 1998: 207). 


\section{Literature and agents}

These fundamental insecurities distinguish the spy from the detective and the front pig. The detective may be ever so insecure about who and what may be trusted in the world of crime and police, but his own common sense is unshaken, even if he is disillusioned about everything else; his own mission, be it with or without success, is basically out of the reach of doubt. The front pig may be ever so let down and deserted by superordinates and under attack from enemies, left behind in the most meaningless and disillusioned battle on Earth - but his own and his front pals' fundamental fight for survival provides a firm ground of reality not to be shaken. Before we go on to investigate the spy novel's relation to these a priori structures in the ontology of espionage, it is worth mentioning that exactly the insecurities mentioned give writings about espionage a particular relation to categories like fact and fiction. Even the memoir writing on indubitable spies is ripe with paragraphs to which they themselves are the only possible or only actual sources. This implies that they may have taken themselves all possible freedoms when describing the events in question, just like they may owe different persons and organizations to cut things out or color the narration in various ways. The insecurity moment in the very object thus implies that a potential fictivity sticks to even the most well documented spy accounts. It is very few other domains which could give rise to volumes like the Faber Book of Espionage (West 1993) which as matter of course mixes up excerpts from spy novels with dito memoirs. Ian Fleming side by side with Kim Philby, Graham Greene with George Blake, Somerset Maugham with "Dusko" Popov. This intricate relation between espionage and literature is also emphasized by the fact that very many agent novel authors possess a first hand knowledge about the business. This includes Fleming, le Carré, Somerset Maugham, Greene - who even worked together with Philby — which is why their works of fiction might be suspected (and are in fact suspected!) for, to larger or lesser extents, to be key novels. Is James Bond a fiction copy of Popov (minus his hump), is Leslie Nicholson the model for Greenes Nobody to Blame, etc. ...?). In the same vein, anecdotes flourish about the really existing organizations having lent inspirations from spy novels or their authors, cf. the idea that Fleming should be the father to CIA's plans of killing Castro by a cigar explosion or infecting him with barber's itch so he would lose his 
charismatic beard and, with it, political power. Thus, there is a fluid borderline between fact and fiction because of the fact that fiction is a core part of the ontology of espionage. This does not imply that a unanimous reality of espionage does not exist - it just entails that we have no methodologically granted access to that reality. ${ }^{26}$ Thus, there is a structural connection between literature and espionage. The author shares central features with the spy in so far he is a (partly) disinterested observer on the margin of the society in which he lives but in addition to this structural analogy, there seems to be an empirically well-founded correlation between writers and intellectuals on the one hand and spys on the other. Already the playwright Christopher Marlowe performed counter-espionage for Queen Elizabeth I and her chief of intelligence Walsington against Mary Queen of Scots and paid with his life for it. Geoffrey Chaucer is said to have spied for John of Gaunt, and the famous French 18th century spy, the Knight of d'Eon (often disguised as Miss Lia of Bermont) was also the author of a treatise on economics. The first intelligence service in England around the Duke of Marlborough involved Daniel Defoe who later became the first leader of organized intelligence in England and thus, in a certain sense, one of the founders of Secret Service. In addition to many deeds as active spy, e.g., against the Scots, he even wrote one of the first papers on intelligence "A Scheme for General Intelligence" (1704). ${ }^{27}$ "Intelligence is the soul of public business," so Defoe, who continues to define counter-espionage: "For as intelligence is the most useful to us, so keeping our enemies from intelligence among us is as valuable a head.", just like he recommends the organisation of archives with files on all potential problem sources. Already Defoe used his literary work as an alibi during information gathering, and he thus forms a prototypical example of a practical connection between the author's and the intellectual's free, wandering lifestyle and their potential use for intelligence purposes.

\footnotetext{
26 We may note that the postmodernist sceptic Jean Baudrillard took his best examples for his radical idea of the "disappearance of the real" from the world of secret services. Who was responsible for the Italian terror bombs of the seventies and eighties? - Many different groupings claimed responsibility, maybe it was instructed by one political wing in order to discredit the other, maybe by the police in order to discredit both, maybe by foreign interests in destabilising Italy ... Reality vanishes behind such interpretations and their effects.

27 I take these informations from Haswell 1979: 48f.
} 


\section{"Existential correlate" and enunciation}

Both the detective, the agent, and the front pig novels are meaningless without some version of a first person narrator perspective - without which the elementary suspense of these genres is difficult to maintain. Omniscient narrators, especially with respect to the time aspect, but also with regard to the inner life of many persons, would spoil these effects, apart from the fact that they would seem unnatural with their unavailable amount of knowledge. But the spy novel seems even more tied to the first person perspective than the other two, in regard to time, space, and persons, because only thus the radical insecurity may be pictured.

This leads to the question of what could be called the "existential correlate" of these genres, that is, their iconic relation to other fields on a higher, secondary level of iconicity. We should of course not suppose that the legitimity of these genres lies only in their ability to allegorize basic existential experiences for the reader. There is a huge amount of direct information about the ontology as well as empirical facts of real milieus and experiences in them, and espionage is in itself, moreover, a complicated facet of existence — but all the same it seems to call for an explanation that these genres possess the mass appeal which they do having made them huge popular genres of the 20 th century. It seems to be connected to the fact that these related genres make possible a bouquet of rather different allegories in relation to other domains of life. The detective genre's affinity to cool intellectual games, solution of enigmas, intelligence tests, a heart of gold behind the tough appearances, lonely cinema noir rainy day melancholy, etc. probably forms the most well-known of these male cocktails. The front pig genre rather has a connection to fundamental feelings of misfit, hatred towards superordinates and ordinary life, violent reaction, radical and unanimous chosing side, bodily primitivism, and the dream of Männerbünde, the blending of blood and unconditional male friendship. The spy genre, on the other hand, lies on a continuum from idealism over the violation of idealism and to mask games, loss of identity, fundamental lack of orientation and insecurity where any supposition about reality may vanish and initiate a foggy Nebenwelt in which a dark and somber worldwide destiny develops unpredictably. The spy may despair, but his loneliness is not the outsider's like the detective's, it is rather the loneliness of being tied to an irreversible position in a structural paranoia where any 
figure like in a puzzle picture may all of a sudden change into its opposite. The connection to politics is of course direct and not allegorical, but in addition to that, these structures seem to give the spy genre a special relationship to love and religion, maybe even the more dark and despairing aspects of the two. Love, jealousy, sex, and so on play marginal roles for the detective and the front pig who may deal with these matters in a unashamed Hemingwayian toughness; for Marlowe or Kelly's Heroes the woman is interesting staffage but no intrinsic issue - but these issues are evidently generic in spy literature. Already in the object itself, there is a connection, cf. the classic features of female spies, both as honeytraps, patiently waiting for the appearance of the classical pillow talk (while maybe the seances are filmed or in other ways documented for use in blackmail). ${ }^{28}$ Here, a common sense insecurity as to the continuum between sex and love is mirrored in a continuum between sex and blackmail. But in addition to these structures in espionage itself, the stable occurrence of these themes in spy literature is probably motivated in the structural analogies in the respective domains which make them obvious to use as allegories for each other. To many literary spies, the mysteries of love seem to be realities into which you may fly when the insecurity on the first level becomes unbearable - just to discover that a structurally analogous insecurity repeats itself at the second level.

A similar analogy of structure which may be a reason behind the popularity of the genre, is theology. We have already remarked upon Carl Schmitt's idea of the theological genealogy of modern political concepts. Theology becomes - via the deism of Enlightenment constitutional law; the priest becomes the lawyer; God becomes the sovereign; epiphany becomes the state of emergency. You may continue yourself: the religious community and the heathens become friend and foe, respectively; atheism and doubt become the ideologies of the bourgeoisie (the "discussing" class trying to evade decision). Just like faith makes only sense for a believer, thus politics requires, according to Schmitt, "existentielle Teilhaben". It is not necessary to join Schmitt in his fascist conclusions to these analogies in order to

28 The first organized use of this effect was probably Bismarck's famous espionage chief Wilhelm Stieber who was the father of many classical espionage inventions. He erected the so-called "Greenhouse" in Berlin, an especially sophisticated and depraved whorehouse, with the intention of its use in blackmail of its customer circle involved in international politics. 
see the spy novel as intensely occupied by a theology of the state. ${ }^{29}$ Democracy to Schmitt was a naive belief in the possibility of the extermination of sovereignty; for a more cool point of view, democracy is rather a strong - if not the only - means to contain and control a sovereign position which can not be exterminated, and among the chief political virtues of democracy is precisely the fact that you need not be existentially aroused by it in order to claim your rights as a political citizen. But the position of sovereignty in democracies is precisely located in the secret services and the (most often, small) central parts of the political elite controlling them. In and around the intelligence organizations, all the theological paradoxes repeat themselves. This goes for the politological understanding of them, but also for the participants: the continuum in espionage from existential bottomlessness and to idealist confession mirrors the continuum from doubt to faith, and just like the ways of the Lord are past understanding, even for the believer, so exactly the same holds for the ways of the State, even for the most devoted spy. He becomes a mystic of the state, be it real or dreamt-up, serving an enigmatic entity which by its very nature never can be met with face to face, which he may only meet in his own doubtful deeds where any victory is provisional, open to dispute and maybe even a defeat in disguise. In theology, the spy novel thus finds another 'existential correlate' and with it all the passions, the rare epiphanies, and the dark-nightsof-the-soul — both in dogmatic theology and popular belief versions.

But here, the espionage novel adds to these existential passions a cool and comfortable objectivation in so far as they are here played out in full intersubjective orchestration. In doing so, the spy genre may stage these existential and theological structures without the first person perspective leading to orgies of expressive psychologisms. Most often, the first person perspective is - in spite of its status as point-of-view - minimally described, exactly because the objective scenario of the plot stages the existential figures. This allows for a cool and objective rendering of structures which in other genres may be given rather juicy and self-indulgent psychological descriptions. ${ }^{30}$

\footnotetext{
29 An explicit example supporting this idea being Graham Greene the catholic.

30 Maybe this fact gives part of an explanation of the often-noticed but relatively unexplained partition of the film and literature public into two segments: a masculine segment preferring the detectives, front pigs, spies, thrill, and objective action of B-movies, while a feminine segment wants children, doctors, artists, love, passion with full possibilities of heavy psychological identification.
} 
This force of the spy novel may be that it orchestrates the passion of the state at the same time as it provides an objective iconic tool to grasp the bottomlessness of love, existence, and theology: a stable instrument to understand a set of basic insecurities.

\section{Iconicity}

To conclude, a basic condition of possibility for the spy novel lies in its iconic use of basic ontological structures of espionage as such, that is, between semantic meaning and reference. A basic outline of this structure can be found in the presuppositions of any definition of the word spy. A further analysis demonstrates a series of structural corollaries to this spy definition:

(1) the spy as a special moment of the narratological hero (as opposed to the related characters, the detective and the front pig);

(2) the positional character of the spy - the possession of secret knowledge as determination independent of any espionage intention or affiliation in the person in question;

(3) a tendential structural difference between foreign and domestic services;

(4) two types of basic insecurities in any espionage hierarchy: one top-down insecurity eroding the superordinates' trust in the subordinates; and one bottom-up insecurity inflicted by the "compartmentalization" of secret services, eroding the spy's trust in the organization employing him;

(5) the secrecy and insecurities of espionage makes fiction a possible aspect of every factual writing about it.

These basic ontological features of espionage is iconically reproduced in the spy novel genre and contributes to its very definition as such. The fifth property, moreover, implies an inner relation - and iconicity - between the role of authors and the role of spies.

Finally, the isolation of these basic properties of espionage makes possible a hypothesis about a second-order iconicity holding between the espionage novel and other discourses, namely those of love and of theology. These two fields structurally share the basic insecurities of espionage which is why it may be used iconically to address, more or less directly, central problems of love and religion.

Thus, iconicity is at stake in at least two different aspects. Basically, an iconicity between espionage as such and the novels about it 
is made possible by shared structural semantics. On this basis, other important iconic relations become possible, namely those between spies and authors and those between espionage on the one hand and love and religion on the other.

This conclusion forms an empirical case against two ideas of the relation iconicity and literature. One is the skepticist idea that iconicity should play no role at all in literature and that, consequently, it should be possible to describe literary issues with literary theoretical concepts only. Against this, it may be argued that the very existence of stable genres - as for instance the spy novel — point to iconical, realist foundations outside of literature proper. Another is the idea that iconicity in literature should concern only the relation between expression and content (like figure poems, basically). Against this, it may be argued that a more basic iconicity concerns also the relation between meaning and reference.

\section{References}

Brandt, Per Aage 1983. Sandheden, sæetningen og døden [Truth, Sentence, and Death]. Arhus: Sjakalen.

Carré, John le 1965 [1963]. The Spy Who Came In From The Cold. London: Gollancz.

Clausewitz, Carl von 1963 [1832]. Vom Kriege. Hamburg: Rowohlt.

Deighton, Len 1986 [1983]. Game, Set, and Match. London: Hutchinson.

Dulles, Allen 1963. The Craft of Intelligence. New York: Harper and Row.

Dumézil, Georges 1979. Interview. Ornicar! [Paris] 19: 69-96.

Greimas, Algirdas Julien 1976. Maupassant. Paris: Seuil.

- 1979. Sémiotique. Paris: Seuil.

- 1982. Du sens II. Paris: Seuil.

Haswell, Jock 1977. Spies and Spymasters. London: Thames and Hudson. Hersh, Seymour M. 1997. The Dark Side of Camelot. Boston: Little Brown.

Hitchcock, Alfred 1955. The Man Who Knew Too Much (screenplay John Michael Hayes), Hollywood.

Keegan, John 1993. A History of Warfare. London: Vintage Books.

Knudsen, Jesper 1999. "Agent, men for hvem?" [“Agent, but for whom?"]. The Copenhagen daily Information 10(3).

Maupassant, Guy de 2000. Deux amis. In: Textes choisis. Paris: Gallimard.

McEwan, Ian 1997 [1987]. The Innocent. London: Picador.

Moynihan, D. P. 1998. Secrecy: The American Experience. New Haven: Yale University Press.

Schmitt, Carl 1963 [1932]. Der Begriff des Politischen. Berlin: Duncker \& Humblot. 
- 1993 [1922, 1933]. Politische Theologie. Berlin: Duncker \& Humblot.

- 1970. Politische Theologie II. Berlin: Duncker \& Humblot.

Smith, Barry 1994. Austrian Philosophy: The Legacy of Franz Brentano. La Salle: Open Court.

- 1996. In defense of extreme (fallibilistic) apriorism. Journal of Libertarian Studies 12: 179-192.

Stjernfelt, Frederik 1990. Baldr og verdensdramaet $i$ den nordiske mytologi [The God Baldr and the Drama of the World in Old Norse Mythology]. Copenhagen: Museum Tusculanum.

- 1997. Den narrative kamp og dens beskrivelse. In Stjernfelt, Frederik, Rationalitetens himmel og andre essays. Copenhagen: Gyldendal, 406-414. [French version: 1995. Récits de l'âgon: leur description linguistique. In Porte, Michèle (ed.), Quand parlent les formes, vol. II. Paris: C.N.R.S., 717732.]

- 1999. How to learn more. An apology for a strong concept of iconicity. In Johansson, Troels Degn; Skov, Martin; Pedersen, Berit Brogaard (eds.), Iconicity - A Fundamental Problem in Semiotics. Aarhus: NSU Press, 21-58.

- 2000. Diagrams as a centerpiece for a Peircean epistemology. Transactions of the Charles S. Peirce Society 36(3): 357-384.

Tunander, Ola 1994. Den usynlige hånd og den hvide — en læsning af Palmemordet [The Invisible Hand and the White Hand - an Interpretation of the Palme Murder]. Kritik [Copenhagen] 110: 77-91.

Weber, Max 1972 [1921]. Wirtschaft und Gesellschaft. Tübingen: J. C. B. Mohr. West, Nigel (ed.) 1993. The Faber Book of Espionage. London: Faber.

\section{Онтология шпионажа в реальности и в литературе: проблема иконичности}

Базовой формой иконичности в литературе является соответствие между базовыми концептуальными схемами в литературной семантике и в мире фактов. Семантика шпионажа зависит от онтологии той области, которая связана с “фаллибилистическим априоризмом” английского философа Берри Смита. В данной статье делается попытка наметить в общих чертах своего рода онтологию, которая основывается на семиотике А. Ю. Греймаса и на философии обстоятельств Карла Шмитта, в связи с чем утверждается, что семантика шпионажа в равной степени содержит в себе политологию и нарратологию. "Позиционный” характер шпионажа анализируется именно исходя из этого. Структурное различие между полицейским и военным шпионажем очерчивается в соответствии с теорией Жоржа Дюмезиля о трех функциях в индоевропейском мышлении. Выделен ряд характерных для шпионажа онтологических “критических поло- 


\section{Frederik Stjernfelt}

жений” и их литературных репрезентаций. Наконец, выдвигается несколько гипотез о связи шпионажа с литературой, обрисовываются некоторые центральные аллегорические объекты шпионского романа (любовь, теология) и делается заключение об иконичности литературы.

\section{Spionaaži ontoloogia reaalsuses ja kirjanduses: ikoonilisuse juhtum}

Ikoonilisuse baasvorm kirjanduses on vastavus kontseptuaalse baasskeemi vahel kirjanduslikus semantikas ja faktide maailmas. Spionaaži semantika on sõltuvuses ontoloogiast selles vallas, mis osutab inglise filosoofi Barry Smithi "fallibilistlikule apriorismile". Antud artiklis püütakse visandada ontoloogia, mis põhineb A. J. Greimasi semiootikal ja Carl Schmitti olukorra filosoofial, väites, et spionaaži semantika sisaldab võrdsel määral politoloogiat ja narratoloogiat. Spiooni "positsionaalset" iseloomu analüüsitakse just sellest lähtuvalt. Strukturaalset erinevust politsei ja sõjaväe spionaaži vahel piiritletakse osutusega Georges Dumézili teooriale kolmest funktsioonist indoeroopalikus mõtlemises. On välja toodud rida spionaažile iseloomulikke ontoloogilisi nö "ebakindlusi" ja nende kirjanduslikud esitused. Lõpuks püstitakse hüpoteese spionaaži ja kirjanduse seose kohta, visandatakse mõned spiooniromaani kesksed allegoorilised objektid (armastus, teoloogia) ja tehakse kokkuvõte kirjanduse ikoonilisusest. 